\title{
GLOSA DO UCHWAEY SĄDU NAJWYŻSZEGO Z DNIA 19 MAJA 2015 R., SYGN. III CZP 114/14
}

\section{COMMENT ON THE JUDGEMENT OF THE SUPREME COURT OF 19 MAY 2015, III CZP 114/14}

\author{
http://dx.doi.org/10.12775/PPOS.2016.007
}

\section{STRESZCZENIE}

Celem glosy jest analiza uchwały Sądu Najwyższego, w której zajął się on zagadnieniem odpowiedzialności dzierżawcy lub zarządcy obwodu łowieckiego lub Skarbu Państwa za tzw. szkodę łowiecką. Ma ono istotne znaczenie praktyczne dla poszkodowanych. W analizowanym orzeczeniu Sąd Najwyższy zajął się także wykładnią pojęcia uprawa rolna. Stanowisko przedstawione w uchwale należy zaaprobować, jakkolwiek nie wszystkie argumenty Sądu Najwyższego, na których oparł on swoje orzeczenie, są trafne.

\section{Słowa kluczowe}

Ochrona przyrody; prawo łowieckie; odpowiedzialność za szkody łowieckie.

Prof. dr hab., Kierownik Katedry Prawa Ochrony Środowiska WPiA UMK w Toruniu. 


\section{ABSTRACT}

Abstract: The aim of this comment is the analysis of the judgement of the Supreme Court, in which the Court dealt with the issue of the liability of a hunting area leaseholder or manager or the State Treasury for so called damage caused by hunting. It has a significant and practical meaning for the aggrieved party. The Supreme Court dealt also with the interpretation of an agricultural field. The stand taken in the judgement should be accepted, however, not all the arguments of the Supreme Court are accurate.

Keywords

Nature protection; hunting law; liability for damage caused by hunting.

\section{TEZA}

Szkodą w uprawie rolnej (art. 50 ust. 1b w związku z art. 46 ust. 1 pkt 1 ustawy z dnia 13 października 1995 r. Prawo łowieckie jedn. tekst: Dz.U. z 2013 r., poz. 1226 ze zm.) jest także szkoda wyrządzona przed zasiewem, związana $\mathrm{z}$ ponownym wykonaniem niezbędnych czynności agrotechnicznych przygotowujących grunt do zasiewu ${ }^{1}$.

I.

Uchwała SN dotyczy kwestii, która wyjątkowo długo jest sporna w orzecznictwie, a jednocześnie, która jest z punktu widzenia aksjologii i funkcjonowania ustawy z dnia 13 października 1995 r. Prawo łowieckie niezwykle istotna. De lege lata problematyka odpowiedzialności za szkody łowieckie jawi się jako jeden $\mathrm{z}$ istotniejszych zagadnień prawa łowieckiego, o dużej

1 Za: LEX nr 1681981, www.sn.pl, Biul.SN 2015/5/12-13, KSAG 2015/3/145 
doniosłości praktycznej, nie tylko z punktu widzenia poszkodowanych, ale także z punktu widzenia podmiotów odpowiedzialnych za szkody łowieckie, a więc dzierżawców lub zarządców obwodów łowieckich, czy też Skarbu Państwa.

Głosowana uchwała jest wypowiedzią SN nie tyle co do samego pojęcia uprawa rolna, ile co do zakresu odpowiedzialności dzierżawcy lub zarządcy obwodu łowieckiego, ewentualnie Skarbu Państwa. Z tych też względów warto podjąć się bliższej analizy zaprezentowanych argumentów. Stanowisko wyrażone w samej uchwale należy w pełni zaaprobować, choć wywód prowadzący do słusznego wniosku nie jest w pełni trafny.

II.

Jak wynika z uzasadnienia samej uchwały, uchwała została podjęta na skutek pytania prawnego przedstawionego przez Sąd Okręgowy w G. rozstrzygającego spór o zapłatę odszkodowania z tytułu szkód łowieckich na skutek apelacji pozwanego Skarbu Państwa - Lasu Państwowego w T., wniesionej od wyroku Sądu Rejonowego w M. Zaskarżonym wyrokiem Sąd Rejonowy zasądził od pozwanego Skarbu Państwa na rzecz R., spółki z ograniczoną odpowiedzialnością z siedzibą w G. kwotę 17.657,64 zł z ustawowymi odsetkami od dnia 28 kwietnia 2012 r. Sąd Rejonowy, uwzględniając w tym zakresie powództwo ustalił, że powodowa spółka jesienią $2011 \mathrm{r}$. na działce o powierzchni 182 ha wykonała planową orkę, aby w tym samym miejscu, na wiosnę 2012 r., zasiać kukurydzę. W kwietniu 2012 r. powódka stwierdziła, że doszło do zniszczenia przez dziki zaoranego pola, co wymagało ponownego przygotowania pola pod zasiew przez zasypanie dołów, talerzowanie i bronowanie. Powód poniósł szkodę, która została wyrządzona przez dziki na jego polu przygotowanym do zasiewu, a więc szkodę w uprawach rolnych. Sąd Okręgowy w G. przytoczył orzeczenia, które mają ilustrować rozbieżność wykładni co do zakresu pojęcia „uprawa rolna” użytego w art. 46 ust. 1 pkt 1 Pr. łow. Zdaniem Sądu Okręgowego, zasada ochrony własności wyrażona w art. 64 ust. 1 i 2 Konstytucji przemawia za tym, by za szkodę w uprawie rolnej uznawać także 
szkody wyrządzone przez zwierzęta łowne przed zasiewem, zwłaszcza jeśli uwzględni się, że posiadacz nieruchomości rolnej nie dysponuje, poza możliwością działań prewencyjnych, żadnymi środkami ochrony przed zachowaniem zwierząt łownych. Postanowieniem z dnia 11 września 2014 r. Sąd Najwyższy przekazał przedstawione przez Sąd Okręgowy zagadnienie do rozstrzygnięcia powiększonemu składowi. Wskazał, że dotychczasowe orzeczenia Sądu Najwyższego koncentrują się na „rolnym” charakterze uprawy i nie dają jednoznacznej odpowiedzi na pytanie o zakres samego pojęcia „uprawa”. Wobec braku ustawowej definicji tego pojęcia zachodzi konieczność odwołania się do jego potocznego rozumienia. W związku z tym zwrócił uwagę na pomijanie jednego ze słownikowych znaczeń pojęcia „uprawa”, tj. przygotowania gleby pod zasiew lub sadzenie roślin. Ostatecznie, zdaniem Sądu Najwyższego, prokonstytucyjna wykładnia funkcjonalna powinna prowadzić do szerokiego ujmowania uprawy i nie ma uzasadnionych podstaw do wyłączenia z niej tych prac i zabiegów agrotechnicznych, które miały na celu przygotowanie gleby pod zasiew lub sadzenie roślin, a tym samym wyłączenia z zakresu podlegających naprawieniu $\mathrm{w}$ trybie przepisów omawianej ustawy szkód polegających na wydatkach poniesionych na te prace lub wydatkach polegających na przywróceniu pola do stanu pierwotnego, skoro w odniesieniu do tego mienia jest to szkoda w postaci straty (lucrum cessans), taka zaś szkoda - zgodnie $\mathrm{z}$ art. $361 \S 2$ k.c. - podlega naprawieniu.

III.

Wbrew temu, co inspirowało SN do podjęcia uchwały w szerszym składzie kluczowy nie tyle jest problem zdefiniowania pojęcia uprawa rolna, ile określenie zasięgu odpowiedzialności dzierżawców, zarządców obwodu łowieckiego i Skarbu Państwa. Tylko pozornie problem dotyczy rozumienia pojęcia uprawa rolna, podczas gdy w rzeczywistości dotyczy on zakresu odpowiedzialności z tytułu szkód łowieckich. Rozważania SN koncentorwały się na wykładni pojęcia uprawa rolna. Tak zresztą został zidentyfikowany problem prawny, 
właśnie jako konieczność dokonania wykładni tego pojęcia. SN szeroko i szczegółowo przeanalizował swoje dotychczasowe stanowisko i uznał, że konieczna jest kolejna jego wypowiedź odnośnie tego pojęcia.

Punktem wyjścia do rozważań SN było stwierdzenie, że nie istnieje legalna definicja pojęcia uprawa rolna, oraz założenie, że konieczne jest dokonanie wykładni językowej z jednoczesną rezygnacją z wykładni systemowej. W tym ostatnim zakresie SN przyjął, iż poszukiwanie ewentualnych normatywnych desygnatów pojęcia uprawa rolna poza ustawą Prawo łowieckie jest niecelowe, gdyż kontekst normatywny używania tego pojęcia w innych ustawach jest odmienny. Doprowadziło to SN do wniosku, iż to samo pojęcie, tj. uprawa rolna jest używane w różnych kontekstach, w zależności od tego, jakie wartości urzeczywistnia dany akt prawny.

Zgodzić się należy z oceną dokonaną przez SN, iż pojęcie uprawa rolna może i budzi poważne wątpliwości interpretacyjne, które zasadniczo sprowadzają się do tych okoliczności, które SN wskazywał. Kierunek zmierzający do przyjęcia, iż pojęcie uprawa rolna należy rozumieć według potocznego znaczenia tego terminu jest w pełni uzasadniony. Jak trafnie zauważa A. Malinowski „w tekście prawnym należy przede wszystkim stosować powszechnie używane, poprawne wyrażenia $\mathrm{w}$ podstawowym znaczeniu, $\mathrm{w}$ jakim występują one w języku ogólnym, wykluczone jest użycie w tekście prawnym jakichkolwiek słów w znaczeniu przenośnym. Użyte określenia powinny być współczesne; określeniom występującym $\mathrm{w}$ tekście powinny być przypisane ich znaczenia podstawowe, słownikowe"2.

Zaaprobować więc należy poszukiwanie przez SN odpowiedzi na pytanie prawne właśnie poprzez zastosowanie potocznego i powszechnego rozumienia pojęcia uprawa rolna. Słusznie też SN za priorytetową przyjął wykładnię językową.

2 A. Malinowski, Polski tekst prawny. Opracowanie treściowe i redakcyjne, Warszawa 2012, s. 21. 
Powszechnie aprobuje się pierwszeństwo tej wykładni w procesie odkodowywania normy prawnej ${ }^{3}$.

Jednocześnie SN preferując wykładnię językową, bronił się przed dokonywaniem wykładni systemowej. Obrona ta została podjęta także z zastosowaniem argumentu egzemplifikacyjnego, polegającego na tym, że SN wskazał na użycie pojęcia uprawa rolna $\mathrm{w}$ innym akcie normatywnym, $\mathrm{z}$ jednoczesnym określeniem, jak należy rozumieć to pojęcie użyte w tym innym akcie prawnym. Podsumował ową egzemplifikację stwierdzeniem, że pojmowanie pojęcia uprawa rolna w ten sposób na płaszczyźnie ustawy Prawo łowieckie jest nieprzydatne.

Jak zauważa L. Morawski „wykładnia systemowa pełni rolę subsydiarną w stosunku do wykładni językowej. Subsydiarność wykładni systemowej polega przede wszystkim na tym, że służy ona do rozstrzygania wątpliwości, które nasuwa wykładnia językowa, a w szczególności pozwala ustalić wybór między różnymi możliwymi interpretacjami danego zwrotu, czy przepisu, ponadto używa się jej do potwierdzenia rezultatu wykładni językowej, a w wyjątkowych sytuacjach motywowanych ważnymi powodami przy jej pomocy uzasadnia się modyfikacje lub nawet odstępstwo od wykładni językowej"4.

W analizowanym przypadku wykładnia systemowa, a dokładniej rzecz ujmując jej zaniechanie, miało uzasadniać określony, szeroki sposób pojmowania pojęcia uprawa rolna, uwzględniający również i zabiegi dokonywane przy ponownym obsianiu gruntu rolnego.

Podstawowym elementem rozumowania SN była ocena znaczenia celowości działań podejmowanych w zakresie uprawy i potrzeba ochrony wysiłku ludzkiego. Choć należy zaznaczyć, że ten akurat element został słabo uwypuklony w samym uzasadnieniu uchwały, zapewne ze względu na szersze w tym zakresie, a wcześniejsze wypowiedzi SN.

Trafnie SN skontatował, iż konsekwentne oddzielanie pojęcia uprawa rolna od płodów rolnych prowadzi do wniosku, iż

3 M. Zieliński, Wykładnia prawa. Zasady, reguty, wskazówki, Warszawa 2010, s. 139 i n.; L. Morawski, Zasady wykładni prawa, Toruń 2010, s. 97.

4 L. Morawski, Zasady wykładni prawa, Toruń 2010, s. 127. 
chodzi w istocie o ochronę dwóch odrębnych wartości. Ochrona płodów rolnych pozostaje zasadniczo niezależna od wkładu, jaki człowiek podjął, dla ich powstania. Liczy się jedynie efekt finalny w postaci powstania takich płodów, niezależnie od włożonego wysiłku, prowadzącego do tego celu. Argumentem przemawiającym za takim sposobem ujęcia problemu jest chociażby art. 48 Prawa łowieckiego, zawierający katalog czynności uchylających obowiązek zapłaty odszkodowania. Dotyczy to w szczególności pkt 5, w którym problematyka ochrony płodów rolnych jest uregulowana niezależnie od ochrony upraw rolnych. W tym jednak wypadku szkoda będzie obejmowała jedynie wartość utraconych płodów. Będzie więc miała wymiar typowej straty rzeczywistej. Ustawodawca w tym wypadku nie chroni już samego wysiłku posiadacza tych płodów, prowadzący do ich uzyskania. Chroni jedynie wartość majątkową jaką owe płody mają. Trudno bowiem uznać, że ochronie podlega wysiłek polegający na utworzeniu stogu, sterty lub kopca.

Dostrzeżenie odrębnego ujmowania przez legislatora upraw rolnych i płodów pozwala na poszukiwanie zasadności wyodrębnienia tych dwóch wartości i objęcia ich częściowo wspólną, ale nie zawsze ochroną. SN dostrzegł różnicę właśnie w owym wysiłku ludzkim i wkładzie określonego podmiotu, także jego pracy, które miały doprowadzić do określonego efektu końcowego. Można byłoby wręcz postawić tezę, iż właśnie potrzeba ochrony wysiłku ludzkiego i trudu włożonego $\mathrm{w}$ zagospodarowanie gruntu rolnego zgodnie $\mathrm{z}$ jego społeczno - gospodarczym przeznaczeniem, połączona z podkreślaną przez SN niemożnością podjęcia działań ochronnych przeciwko uszkadzaniu owych płodów przez zwierzęta, jest ową wartością prawem chronioną. Świadczy też o tym umieszczenie art. 46 ust. 1 pkt 1 i art. 50 ustawy Prawo łowieckie w ramach odrębnego rozdziału, dotyczącego właśnie szkód łowieckich. A. Malinowski trafnie podkreśla, iż „nie budzi wątpliwości pogląd, iż systematyka wewnętrzna ustawy ma znaczenie normatywne, systematyka ta wprawdzie nie wyraża wprost norm prawnych (tak, jak przepisy prawne), jednak w przypadku poprawnie sporządzonej systematyki wewnętrznej ma ona istotne znaczenie dla ustalania treści norm prawnych zakodowanych w poszcze- 
gólnych przepisach zawartych w tekście prawnym, tzn. pełni znaczącą rolę w procesie wykładni" ".

$\mathrm{W}$ tym zakresie należy podzielić pogląd $\mathrm{SN}$ i w pełni się z nim zgodzić.

Jednak zagadnienie będące przedmiotem pytania prawnego wcale nie sprowadzało się w mojej ocenie do wykładni pojęcia uprawa rolna, ale do określenia zakresu odpowiedzialności za szkody łowieckie. SN zdawał się dostrzegać ten właśnie element, gdyż powołując się na wykładnie prokonstytucyjną wskazywał, iż przywrócenie do stanu poprzedniego poprzez dokonywanie pewnych zabiegów agrarnych mieści się w pojęciu utraconych korzyści.

W rozumowaniu SN dostrzec można jednak pewne niekonsekwencje. Przywoływana wykładnia prokonstytucyjna kieruje uwagę na wartości, jakie podlegają ochronie i które w drodze wykładni powinny być urzeczywistniane. Nie ulega wątpliwości, iż chodzi o ochronę prawa własności, gdyż sam SN wskazywał na konstytucyjne podstawy tejże ochrony, a przede wszystkim na art. 64 Konstytucji RP. Jednak jeśli już uznano, iż u podstaw rozszerzonej wykładni leży potrzeba ochrony własności, to przede wszystkim SN winien rozważyć zastosowanie roszczeń służących tejże ochronie w pierwszej kolejności, a tego nie uczynił. Przyjęto bowiem, że szkoda polega na konieczności przywrócenia stanu poprzedniego poprzez dokonanie określonych zabiegów agrarnych i zasiewów. Tego typu sytuacja jest charakterystyczna dla roszczenia negatoryjnego. Właśnie w odniesieniu do tego roszczenia ustawodawca przewiduje obowiązek przywrócenia do stanu zgodnego z prawem. Wprawdzie nie jest to zawsze stan poprzedni, niemniej jednak akurat w tym wypadku zachodziłaby tożsamość.

Trzeba jednak zauważyć, co uszło uwadze SN, iż problematyka odpowiedzialności za szkody łowieckie wcale nie wiąże się jedynie z ochroną własności gruntu. Wniosek taki można prima facie wyprowadzić z art. 47 ust. 2 Prawa łowieckiego, zgodnie z którym „w przypadku gdy pomiędzy właścicielem

5 A. Malinowski, Systematyka wewnętrzna ustawy, Warszawa 2007, 
lub posiadaczem gruntu a dzierżawcą lub zarządcą obwodu łowieckiego powstał spór o wysokość wynagrodzenia za szkody, o których mowa w art. 46, strony mogą zwrócić się do właściwego ze względu na miejsce powstałej szkody organu gminy w celu mediacji dla polubownego rozstrzygnięcia sporu". Według tego przepisu właściciel lub posiadacz gruntu jest synonimem poszkodowanego. Jednak w art. 48 pkt 2 i 3 Prawa łowieckiego wskazuje się wyraźnie jedynie na posiadaczy i to bez określania, czy jest to posiadanie na podstawie tzw. tytułu prawnego. Zatem nie tylko o ochronę własności i o ochronę praw majątkowych w przedmiotowej sprawie chodzi.

Słusznie więc poszukiwano odpowiedzi na pytanie prawne nie na płaszczyźnie środków ochrony prawnej prawa własności, tylko na płaszczyźnie zasad odpowiedzialności cywilnej, wynikającej ze stosunków zobowiązaniowych. Tym samym odwoływanie się do ochrony prawa własności należy uznać za nietrafny kierunek, choć ostatecznie doprowadził on SN do trafnego wniosku.

Przyjmując za punkt wyjścia zasadę naprawy szkody w pełnej wysokości, uznać należy, że zakres odpowiedzialności dzierżawcy lub zarządcy obwodu łowieckiego, a nawet i Skarbu Państwa, obejmujący również wydatki poniesione na ponowne zasiewy i związane $\mathrm{z}$ tym zabiegi agrarne, jest w pełni uzasadnione. Przede wszystkim istotny jest mechanizm takiej odpowiedzialności. Również i w przypadku zniszczonego, zaoranego pola $\mathrm{w}$ grę wchodzi określone zachowanie zwierząt, w tym wypadku dzików. Konsekwentnie posiadacz tego gruntu rolnego nie mógł zapobiegać szkodzie na zasadach ogólnych, choć nie poniósł szkody ani w zakresie upraw, których jeszcze nie było, ani w zakresie płodów, których tym bardziej jeszcze nie było. Co jednak istotne podjęty już został określony wysiłek ludzki i poniesiono trud, a więc doszło do urzeczywistnienia już tej wartości, której ochrona leży u podstaw odpowiedzialności za szkody łowieckie w uprawach i płodach rolnych.

Słusznie więc przyjęto, że również i dokonywanie zabiegów pod ponowny zasiew zasługuje na ochronę, gdyż podjęto już wysiłek, a zabiegi agrarne miały charakter działań celowych. 
Pozostaje jednak rozważyć, czy rzeczywiście jednak w grę wchodzi szkoda rozumiana jako lucrum cessans. W piśmiennictwie powszechnie przyjmuje się, że szkoda rozumiana jako lucrum cessans obejmuje utracone korzyści. Uszczerbek o charakterze majątkowym może obejmować utratę korzyści, jakiej poszkodowany mógł się spodziewać, gdyby szkody mu nie wyrządzono; wskutek doznania tej postaci uszczerbku poszkodowany nie staje się bogatszy, jakkolwiek mógł liczyć na wzbogacenie się; mógł go oczekiwać 6 . Podobnie ujmuje ten problem M. Kaliński, wskazując, iż lucrum cessans to korzyści, które mógłby osiągnąć poszkodowany, gdyby mu szkody nie wyrządzono ${ }^{7}$. Choć w innym opracowaniu ten sam autor rozbudowuje kwestię utraconych korzyści wskazując, iż może ona mieć postać m.in. utraconych zarobków, utraconych zysków z przyszłej transakcji, utratę pożytków i przychodów z rzeczy i utratę możliwości korzystania z rzeczy ${ }^{8}$. Wskazuje on też na szkodę przyszłą, jako przykład utraconych korzyści, przy czym definiuje owe damnum futurum jako utratę dochodów z pracy lub plonów9 9

$\mathrm{W}$ analizowanym przypadku utraconymi korzyściami byłyby oczekiwania wynagrodzenia (zarobku), związanego z dokonanymi zasiewami, a następnie zbiorami. Mogłaby to być również ewentualnie szkoda polegająca na tym, że później dokonany zasiew przyniósł plony o mniejszej wydajności w stosunku do tych, których dokonano wcześniej. Natomiast za utracone korzyści trudno uznać wydatki poniesione na ponowny zasiew i dokonanie określonych zabiegów agrarnych. Te wydatki służyły przywróceniu stanu poprzedniego. Mają więc postać szkody rzeczywistej. Nie będzie to więc nawet damnum futurum.

Jednak ta kwestia nie wpływa ostatecznie na ocenę trafności wypracowanego przez SN poglądu, iż zabiegi przywracające zasiewy, zniszczone na skutek aktywności dzika, podlegają

6 W. Czachórski, A. Brzozowski, M. Safjan, E. Skowrońska-Bocian, Zobowiąania. Zarys wykładu, Warszawa 2009, s. 89.

7 M. Kaliński, Szkoda na mieniu i jej naprawienie, Warszawa 2014, s. 20.

8 M. Kaliński, [w:] System prawa prywatnego, t. 6, Prawo zobowiąań część ogólna, A. Olejniczak (red.), Warszawa 2009, s. 115.

9 Ibidem, s. 115-116. 
zwrotowi przez dzierżawcę lub zarządcę obwodu łowieckiego, albo przez Skarb Państwa.

\section{IV.}

Reasumując, samą regułę przyjętą przez SN, należy uznać za prawidłową. Wątpliwości budzą jednak pewne motywy, które doprowadziły SN do takiego, a nie innego wniosku. Przede wszystkim jeśli przyjąć, co jest kierunkiem właściwym, iż wartością leżącą u podstaw konstrukcji odpowiedzialności za szkody łowieckie w uprawach i płodach rolnych jest potrzeba ochrony celowego ludzkiego wysiłku, to nie należy go wiązać z ochroną własności. Wysiłek ten wcale nie musi być wysiłkiem właściciela, a posiadacza. Stąd też kierunek odwołujący się do ochrony prawa własności i wykładni prokonstytucyjnej nie był właściwy.

Bez wątpienia ów celowy, ludzki wysiłek na taką ochronę zasługuje, tym bardziej, co słusznie spostrzeżono, że pole ochrony tego wysiłku poprzez podejmowanie działań prewencyjnych jest bardzo ograniczone, a to ze względu na istniejący konflikt wartości. Z jednej strony występuje ochrona upraw i płodów rolnych, a z drugiej potrzeba ochrony wymienionych w normie prawnej zwierząt.

Problem, który pojawił się w głosowanej uchwale dotyczy nie tyle wykładni pojęcia uprawa rolna, a oceny zakresu odpowiedzialności podmiotów zobowiązanych do naprawienia szkody. Diagnozy tej nie może zmienić nawet dokonywany przez SN zabieg wykładni gramatycznej z odwoływaniem się do językowego pojmowania pojęcia uprawa także jako samych zabiegów przygotowawczych do zasiewu. Trudno temu kierunkowi odmówić racji, jednak problem dotyczy zakresu odpowiedzialności, a nie rozumienia pojęcia uprawa rolna.

W tym też kontekście trafne jest odwołanie się do reguły naprawienia szkody w pełnej wysokości, gdyż to ona wyznacza ostateczne granice odpowiedzialności podmiotów zobowiązanych do naprawienia szkód łowieckich.

Kontakt e-mail:

kpos@umk.pl 